\title{
Factors influencing the effectiveness of internal control in cement manufacturing companies
}

\author{
Tu Chuc Anh ${ }^{a^{*}}$, Lan Huong Tran Thi ${ }^{b}$, Huy Pham Quangc and Thuy Truong Thi ${ }^{a}$
}

${ }^{a}$ Academy of Finance, Hanoi, Vietnam

${ }^{b}$ Hong Duc University, Vietnam

${ }^{c}$ Ho Chi Minh Economics University, Vietnam

C H R O N I C L E

\begin{tabular}{l}
\hline Article history: \\
Received: June 142019 \\
Received in revised format: July \\
252019 \\
Accepted: August 5, 2019 \\
Available online: \\
August 5, 2019 \\
\hline Keywords: \\
Cement company \\
Internal control \\
Effectiveness \\
Effectiveness of International \\
control
\end{tabular}

Received: June 142019

Received in revised format: July

252019

Available online:

August 5, 2019

Keywords:

Cement company

Effectiveness

control

\author{
A B S T R A C T
}

This research approaches and used the 2013 Internal Control-Integrated Framework issued by the Committee of Sponsoring Organizations of the Treadway Commission (COSO) with a view to assessing the impact of the factors: (1) Control environment, (2) Risk assessment, (3) Information and communication, (4) Control activities and (5) Monitoring on the effectiveness of internal control at cement companies. The research was carried out through a survey of 210 managers and employees at Vietnamese cement companies with the support of SPSS software and assessed scale reliability through using the Cronbach`s Alpha coefficient and the method of exploratory factor analysis (EFA). The research results show that the factors above had positive relationship with the effectiveness of internal control. Also, on such basis, the author gave recommendations for maintaining and promoting the effectiveness of internal control to managers at cement companies.

(C) 2020 by the authors; licensee Growing Science, Canada

\section{Introduction}

Internal control plays an important role in preventing and discovering risks, truly and fairly provides financial information, strengthening compliance and improving operational efficiency. Realizing such importance, cement companies have established and carried out internal controls in various forms. Internal control does not only control of an entity's department but also the process including procedures and regulations intended for all departments to ensure that corporate managers can perform functions of reporting, compliance and operation. However, establishing and efficiently carrying out internal controls is now a factor in which managers at cement companies take a great interest. Internal control is an extremely important function of corporate governance. For this reason, to improve governance efficiency, promoting the effectiveness of internal control is necessary (Suyono \& Hariyanto, 2012). Internal control which is efficiently maintained will help entities achieve objectives in terms of not only report and compliance but also operation.

\footnotetext{
* Corresponding author. Tel.: +084-912 034509

E-mail address: chucanhtu@hvtc.edu.vn (T. Chuc Anh) 


\section{Literature review}

Research on the factors affecting the effectiveness of internal control is basically based on 5 parts of the COSO's internal control in 1992 including: Control environment, risk assessment, control activities, information and communication systems, and monitoring. The scale of factors is summarized in Table 1, which is the summary of scale of factors affecting the effectiveness of internal control.

Table 1

The summary of the factors influencing on the effectiveness of internal control

\begin{tabular}{|c|c|c|c|}
\hline Factors & Research & Measurement & Impact \\
\hline Control Enviroment & $\begin{array}{l}\text { Amudo \& Inanga (2009), Ho (2016), } \\
\text { Gamage et al. (2014), } \\
\text { Nguyen (2018) }\end{array}$ & $\begin{array}{l}\text { - Management and operating philosophy } \\
\text { - Integrity and moral values } \\
\text { - Commitment to competence } \\
\text { - Organizational structure } \\
\text { - Human resources policies }\end{array}$ & Possitive \\
\hline Risk Assessment & $\begin{array}{l}\text { Walker (1999), COSO, (2013), } \\
\text { Amudo \& Inanga (2009), Ho (2016), }\end{array}$ & $\begin{array}{l}\text { - Determine the target } \\
\text { - Identify risks } \\
\text { - Risk assessment }\end{array}$ & Possitive \\
\hline Control Activities & $\begin{array}{l}\text { Walker (1999), COSO, (2013), } \\
\text { Amudo \& Inanga (2009), Ho (2016), } \\
\text { Pham (2018) }\end{array}$ & $\begin{array}{l}\text { - Assignment, assignment, authorization } \\
\text { - Physical control activities } \\
\text { - Control the information processing process } \\
\text { - Control policies and procedures } \\
\text { - Control technology }\end{array}$ & Possitive \\
\hline $\begin{array}{l}\text { Information and } \\
\text { Communication }\end{array}$ & $\begin{array}{l}\text { COSO, (2013), Amudo \& Inanga } \\
\text { (2009), Ho (2016), Pham (2018) }\end{array}$ & $\begin{array}{l}\text { - Internal communication, external communication } \\
\text { - Information provided accurately, appropriately and promptly } \\
\text { - Accounting information system }\end{array}$ & Possitive \\
\hline Monitoring & $\begin{array}{l}\text { COSO, (2013), Amudo \& Inanga } \\
\text { (2009), Ho (2016) } \\
\text { Nguyen (2018), Pham (2018) }\end{array}$ & $\begin{array}{l}\text { - Regular monitoring } \\
\text { - Periodic monitoring } \\
\text { - Internal audit } \\
\text { - Periodic monitoring with weaknesses of Internal control }\end{array}$ & Possitive \\
\hline $\begin{array}{l}\text { The effectiveness of } \\
\text { Internal control }\end{array}$ & $\begin{array}{l}\text { COSO, (2013), Amudo \& Inanga } \\
(2009) \text {, Ho (2016), }\end{array}$ & $\begin{array}{l}\text { - Report objectives } \\
\text { - Compliance objectives } \\
\text { - Operational objectives }\end{array}$ & \\
\hline
\end{tabular}

\subsection{Control environment}

"The control environment is the set of standards, processes, and structures that provide the basis for carrying out internal control across the organization. The board of directors and senior management establish the tone at the top regarding the importance of internal control and expected standards of conduct" (COSO 2013). Usually, control environment consists of the following factors: managers' integrity and ethical values, leadership philosophy and operating style; organizational structure; assignment of authority and responsibility; personnel policy; planning; management engagement; and some other factors. The role of control environment is to provide a key foundation for activities because organizational values cannot rise above the integrity and ethics of the people who create, administer and monitor them (Rae \& Subramaniam, 2008). Efficient control environment has a great impact on the entire internal control system. The fact that internal control is carried out efficiently or inefficiently depends mainly on such foundation; therefore, this is the most important component for providing a solid foundation for the design and operation of an entity's internal control system.

\subsection{Risk assessment}

The IIA's International Standards define a risk as 'the possibility of an event occurring that will have an impact on the achievement of objectives'. Risks may be financial, operational, legal/regulatory, or strategic in nature. When risks happen, it is likely that an entity will not achieve the set objectives. Risk management is a process designed to prevent or minimize risks (Walker, 1999), and therefore it helps the entity avoids not achieving their main goals. Risk assessment is an important part in risk management (Pham, 2018). Risk assessment is the process of detecting, assessing and determining how to succeed these things (Gamage et al., 2014; Ratcliffe \& Landes, 2009). Risk assessment helps an entity have the 
best risk management measure. Thus, the establishment and implementation of risk assessment measures will have an impact on internal control efficiency.

\subsection{Information and communication}

The study of Gamage and Low Lock (2014), Ho (2016) and Nguyen (2018) have shown that information and communication is an important factor affecting the effectiveness of the Internal Control systems. All researchers have confirmed that the information and communication system well designed have a positive effect on the effectiveness of internal control in the enterprise. Information must be determined reliably from both inside and outside the enterprise, to be informed and handled by people with functions in a timely manner. "Information is necessary for the entity to carry out internal control responsibilities in support of achievement of its objectives. Communication occurs both internally and externally and provides the organization with the information needed to carry out day - to - day internal control activities. Communication enables personnel to understand internal control responsibilities and their importance to the achievement of objectives" COSO (2013). Therefore, If the communication and information system is well designed and operated, it will help employees understand and perform correctly their tasks, contributing to improve the internal control efficiency in the unit.

\subsection{Control activities}

According to COSO (2013), "control activities are actions that are established by policies and procedures to ensure that management directives for reducing risks and achieving an entity's objectives have been being implemented". Control activities are carried out at all levels of an entity, in various stages of the business process and in technology environment (Pham, 2018). They can include a series of manual and automatic activities such as authorizations, approvals, verifications, reconciliations and reviews of operating performance and can be designed to prevent or review the implementation of management directives. Therefore, if higher efficiency control activities achieve, more effective internal control is achieved.

\subsection{Monitoring}

Monitoring is one of the most important aspects of internal control in any organization. According to Nguyen (2018) and Pham (2018), monitoring the performance of the internal control system over time, made continuous or separate assessment. The purpose of the monitoring is to determine the internal control made properly, fully and efficiently as designed all five components. Monitoring activities include ongoing evaluations, separate evaluations, or some combination of the two. Ongoing evaluations are built into the routine operations and are performed on a real-time basis. A separate evaluation is conducted periodically by objective management personnel, internal audit, and external parties. The scope and frequency of separate evaluations is a matter of management judgment (COSO, 2013). Surrounding this point, monitoring is performed based on 2 principles: The organization selects, develops, and performs ongoing and/or separate evaluations to ascertain whether the components of internal control are present and functioning; Also, evaluates and communicates internal control deficiencies in a timely manner to those parties responsible for taking corrective action, including senior management and the board of directors, as appropriate. Hence, it helps internal control perform more effectively.

\section{The proposed model}

Based on results of previous researches carried out by other authors, the presented theoretical basis and the actual research at cement companies, the author proposed a research model for factors affecting the effectiveness of internal control at cement companies according to the 2013 Internal Control - Integrated Framework as Fig. 1. 


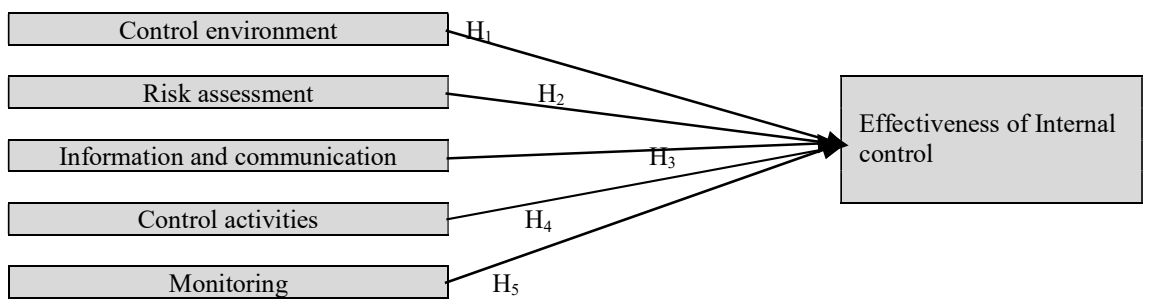

Fig. 1. The proposed model (Source: Results of the author's synthesis, 2019)

Research Model for factors affecting effectiveness of internal control at cement companies

Given objectives, scope and the research model for factors affecting the effectiveness of internal control at cement companies as well as the basic theory presented above, research hypotheses are posited as follows:

Hypothesis $\mathrm{H}_{1}$ : Control environment has a positive impact on the effectiveness of internal control at cement companies;

Hypothesis $\mathrm{H}_{2}$ : Risk assessment has a positive impact on the effectiveness of internal control at cement companies;

Hypothesis $\mathrm{H}_{3}$ : Information and communication has a positive impact on the effectiveness of internal control at cement companies;

Hypothesis $\mathrm{H}_{4}$ : Control activities have a positive impact on the effectiveness of internal control at cement companies;

Hypothesis $\mathrm{H}_{5}$ : Monitoring has a positive impact on the effectiveness of internal control at cement companies.

\subsection{Research methodology}

The authors use two research methods at the same time: Qualitative method and quantities method. Qualitative method is used to determine the groups of factors that affect the effectiveness of internal control at the cement companies. Quantities research method is primarily used in research as: Cronbach's Alpha reliability Testing, EFA discovery factor Analysis, KMO coefficient analysis based on primary data by survey questionnaire on 250 managers and staffs in cement companies. After 1 month, emitting 250 surveys which are designed following 5-level Likert Scale, from "Totally disagree" to "Totally agree". Survey method through stratified random sample (sex, age, division and position) from August $1^{\text {st }}, 2018$ to August $31^{\text {st }}$, 2018. Consequently, emitted 250 surveys, the authors gathered in 210 valid surveys to put into research using SPSS software. Table 2 show personal characteristics of the participants and Table 3 shows the questions of the survey.

Table 2

Personal characteristics of the participants

\begin{tabular}{llcc}
\hline & Content & Number & Proportion (\%) \\
\hline \multirow{2}{*}{ Sex } & Male & 65 & 31.0 \\
& Female & 145 & 69.0 \\
\hline \multirow{3}{*}{ Age } & From 30-40 & 25 & 11.9 \\
& From 40-50 & 73 & 34.8 \\
& From 50 and over & 109 & 51.9 \\
\hline \multirow{3}{*}{ Division } & Board of Management & 61 & 22.4 \\
& Board of Directors & 47 & 29.0 \\
& Controlling division & 65 & 31.0 \\
\hline \multirow{2}{*}{ Current position } & Other division & 37 & 17.6 \\
\hline & Manager & 96 & 45.7 \\
\hline
\end{tabular}


Table 3

Questionnaires

Measurement

ENVIROMENT CONTROL

Integrity and moral values

1. Code of conduct or rules on ethical values are established and clearly communicated to managers, employees, departments through writing or actions.

2. Code of conduct is established based on ethical standards, relevant legal provisions and business regulations

Management and operating philosophy.

1. The Board of Management / Board of Supervisors understands and monitors the implementation of responsibilities for stakeholders.

2. The Board of Management approves and implements policies to support internal control activities.

3. The management board / control board ensures independence in monitoring.

Organization structure

1. Functions, powers and responsibilities and coordination among departments are clearly defined in writing

2. Departments clearly understand the responsibilities in implementing internal control targets.

3. Ensuring the control principles.

Management philosophy and operating style

1. Management perspective of enterprises is always to ensure compliance with the regulations of the State, industry and enterprises

2. Administrators make every effort to ensure that all tasks are completed as planned and achieve the set objectives.

3. The administrator strives to achieve the goal of financial reporting on time and reasonably honest.

Commitment to competence and HR policies

1. Policies and procedures for recruitment of personnel are clear and transparent.

2. The key positions always meet the requirements of the job

3. Human resources are trained and fostered to improve their qualifications in accordance with the changes from internal enterprises, environment, institutions, regulations ...

4. Enterprises formulate appropriate standards and methods for evaluating work results, and results are communicated specifically to each individual.

5. Policies on salary, bonus, welfare and discipline are clear and appropriate

RISK ASSESSMENT

Determine the targets

1. Operational, compliance and reporting objectives are set clearly and appropriately.

2. Identify goals that take into account the appropriate risk

3. The objectives of enterprises are clearly and fully communicated to all employees

4. Enterprises conduct periodic evaluations for the achievement of objectives

Risk Identification and Assessment

1. Considering costs - profits in the process of identification and risk assessment.

2. Risk identification is carried out at all levels, departments, functions and activities in enterprises

3. Using appropriate methods to identify and assess risks

4. Enterprises have appropriate strategies to deal with risks

Change management

1. Enterprises predict, identify and deal with changes in factors

2. Regularly assess the impact of changes and make adjustments to internal control.

CONTROL ACTIVITIES

Control technology

1. Control activities ensure that rights and content accessed is limited to authorized persons.

2. Enterprises control data centers and network systems and computers

3. Enterprises control applications and software

Control policies and procedure

1. Policies and control procedures consistent with the objectives of enterprises.

2. Control policies and procedures are documented and clearly communicated to all employees.

3. Policies and procedures specify the scope of application, roles and functions of the relevant departments.

4. Control policies and procedures are developed in accordance with each activity, function, and job.

5. Control activities are carried out by qualified individuals and departments at the right time.

6. Businesses periodically carry out reevaluation of policies and procedures and make adjustments if necessary.

Control Activities

1. Physical control activities ensure that property is protected from access by unauthorized persons

2. Control to ensure that all operations are verified with validity and legality before recording.

3. Control ensures the transactions are fully recorded

4. Control to ensure that transactions are recorded in the right order and ensure the control process.

5. Control activities take place regularly, including in all activities

COMMUNICATION AND INFORMATION SYSTEM

Communication

1. The communication channel of enterprises allows their subordinates to easily and promptly reflect related issues to functional superiors.

2. Information about tasks, requests from superiors are clearly communicated, to the right people, at the right time.

Information system

1. Information system ensures information is provided promptly, fully and completely in accordance with information needs

2. Information system ensures easy access to information, convenient to use.

3. Information system ensures information is kept confidential and stored securely.

4. Information is fully integrated into the reports and serves the manager in decision making

5. Enterprises perform well in providing honest, relevant and timely information to external audiences.

MONITORING

Ongoing monitoring

1. Enterprises monitor regularly for major activities to ensure results meet the set objectives.

2. Monitoring activities in enterprises are carried out in accordance with the scope and nature of activities, risk levels and changes in the enterprise

3. The monitoring process is established in the processes, business activities, functions of the enterprise.

Periodic monitoring

1. Enterprises perform well self-assessment and cross-evaluation among departments and divisions.

2. Periodic monitoring activities are performed well by objects inside or outside the enterprise

Evaluating and fixing weaknesses of Internal Control

1. Limitations of Internal control are detected by monitoring timely.

2. Administrators respond promptly and in accordance with the limitations of internal control identified.

2. Administrators respond promptly and in accor

EFFECTIVENESS OF INT
1. Reported Objectives

2. Compliance Objectives

3. Operational Objectives

Synthesizing and developing from Amudo \& Inanga (2009),

Ho (2016),

Low and Lock (2014)

Nguyen (2018)

Synthesizing and developing from

Walker (1999), COSO,

(2013), Amudo \& Inanga

(2009), Ho (2016), 


\section{The results}

Preliminary assessment of the reliability of scale with Cronbach's Alpha coefficient, the verification result of five independent variables are the Control Environment (MTKS), Risk Assessment (DGRR), Information and Communication (ICT), Control Activities (HDKS) and Monitoring (GS) of components of the scale are all greater than 0.6 , as Table 4 and considering Corrected Item-Total Correlation of observing variables have achieved a detection requirement greater than 0.3 (Hair \& partner, 2006). For MTKS variable, the MTKS 5 variables have a Corrected Item-Total Correlation 0.245 , less than 0.3 so that MTKS 5 variable was eliminated, the second running of Cornbrash's Alpha coefficient is 0.787. Similarly, for monitoring variable, G1 variable has a Corrected Item-Total Correlation 0.273 so that GS1 variable was eliminated, the result of the second running of Cronbach's Alpha coefficient is 0.816. After the data processing of Cornbrash's Alpha coefficient type 02 variables were MTKS 5 and GS 1, keeping 21 independent variables and 03 dependent variables for the analysis of EFA Discovery Factor.

\section{Table 4}

The results of the Cronbach Alpha coefficients

\begin{tabular}{|c|c|c|c|}
\hline Variables & Influence Factors & $\begin{array}{l}\text { Corrected Item- } \\
\text { Total Correlation } \\
\text { Coefficient }\end{array}$ & $\begin{array}{l}\text { Cronbach`s Alpha } \\
\text { If Item Deleted }\end{array}$ \\
\hline \multicolumn{4}{|c|}{ Cronbach's Alpha Coefficient of Control Environment variable is 0.746} \\
\hline \multirow{5}{*}{$\begin{array}{l}\text { MTKS - Control Environ- } \\
\text { ment, } \\
\text { Angella \& Eno L. Inanga } \\
\text { (2009), Gamage \& Kevin } \\
\text { Low } \\
\text { Lock \& Fernando (2014) }\end{array}$} & $\begin{array}{l}\text { Managers try to maintain a controlled environment on the basic of honesty, } \\
\text { open- hearted, and respect for moral values }\end{array}$ & .463 & .718 \\
\hline & All manage policies and procedures are set up and widely disseminate. & .641 & .651 \\
\hline & $\begin{array}{l}\text { Nowadays, the company has promulgated full legal documents on responsibil- } \\
\text { ities and duties of each position and individual }\end{array}$ & .607 & .662 \\
\hline & $\begin{array}{l}\text { Among all of the parts, has guaranteed relative independence and cross-check- } \\
\text { ing ability. }\end{array}$ & .616 & .662 \\
\hline & $\begin{array}{l}\text { The policies of recruitment, training, promotion, reward and discipline are open } \\
\text { and fully meet the requirements of promoting the strength of human resources }\end{array}$ & .245 & .787 \\
\hline \multicolumn{4}{|c|}{ Cronbach's Alpha Coefficient of Risk Assessment variable } \\
\hline \multirow{4}{*}{$\begin{array}{l}\text { ĐGRR - Risk Assessment, } \\
\text { Sultana \& Haque (2011), } \\
\text { Gamage \& Kevin Low } \\
\text { Lock \& Fernando (2014) }\end{array}$} & $\begin{array}{l}\text { Risk assessment activities are conducted continuously at three levels: short, } \\
\text { medium and long term }\end{array}$ & .550 & .667 \\
\hline & Risks are identified and properly evaluated & .535 & .675 \\
\hline & Risks assessment methods are applied flexibly and effectively & .580 & 648 \\
\hline & $\begin{array}{l}\text { Capacity, qualification of the leadership team meets the requirements of risk } \\
\text { identification and assessment }\end{array}$ & .456 & .720 \\
\hline \multicolumn{4}{|c|}{ Cronbach's Alpha Coefficient of Control Activities variables is 0.85} \\
\hline \multirow{6}{*}{$\begin{array}{l}\text { HĐKS - Control Activities, } \\
\text { Gamage \& Kevin Low } \\
\text { Lock \& Fernando (2014) }\end{array}$} & Control Activities is implemented by managers at all levels. & .596 & .832 \\
\hline & $\begin{array}{l}\text { The result of risk assessment is the basic of the establishment of control poli- } \\
\text { cies. }\end{array}$ & .635 & .825 \\
\hline & Control policies are set up properly, appropriately and effectively implemented. & .546 & .850 \\
\hline & $\begin{array}{l}\text { All control policies and procedures are embodied by documents and imple- } \\
\text { mented to each other. }\end{array}$ & .610 & .830 \\
\hline & Continuous control activities are adjusted to improve control effectiveness. & .716 & .814 \\
\hline & $\begin{array}{l}\text { High quality human resources are essential to control activities has high effi- } \\
\text { ciency. }\end{array}$ & .767 & .800 \\
\hline \multicolumn{4}{|c|}{ Cronbach's Alpha Coefficient of Information and Communication variables is 0.818} \\
\hline \multirow{4}{*}{$\begin{array}{l}\text { TTTT - Information and } \\
\text { Communication, } \\
\text { Gamage \& Kevin Low } \\
\text { Lock \& Fernando (2014) }\end{array}$} & $\begin{array}{l}\text { The information systems ensure that information is provided from the depart- } \\
\text { ments to the managers and from the managers to the departments in a timely } \\
\text { manner. }\end{array}$ & .635 & .773 \\
\hline & $\begin{array}{l}\text { Synchronized computing is the strength of information and communication sys- } \\
\text { tems. }\end{array}$ & .717 & .734 \\
\hline & Information security issues had guaranteed and hadn't ever made a mistake & .739 & .723 \\
\hline & $\begin{array}{l}\text { Business always ready prepares emergency response plans in case of the failure } \\
\text { of an IT system. }\end{array}$ & .478 & .841 \\
\hline \multicolumn{4}{|c|}{ Cronbach's Alpha Coefficient of Monitoring variables is 0.632} \\
\hline \multirow{4}{*}{$\begin{array}{l}\text { GS -Monitoring, } \\
\text { Sultana \& Haque (2011) } \\
\text { Gamage \& Kevin Low } \\
\text { Lock \& Fernando (2014) }\end{array}$} & $\begin{array}{l}\text { Monitoring and controlling activities are carried out regularly by managers and } \\
\text { staff. }\end{array}$ & .073 & .816 \\
\hline & $\begin{array}{l}\text { Independent audit results are also considered as a monitoring channel for inter- } \\
\text { nal control }\end{array}$ & .540 & .466 \\
\hline & Business set up a system to receive extensive monitoring information channel. & .634 & .399 \\
\hline & Monitoring results are recorded and adjusted in a timely manner. & .540 & .484 \\
\hline \multicolumn{4}{|c|}{ Cronbach's Alpha Coefficient of Effectiveness variables is 0.86} \\
\hline HH -Effectiveness, Sultana & The enterprise ensures reporting objectives & .498 & .836 \\
\hline \& Haque (2011) & The enterprise ensures operational objectives & .599 & .770 \\
\hline $\begin{array}{l}\text { Gamage \& Kevin Low } \\
\text { Lock \& Fernando (2014) }\end{array}$ & The enterprise ensures compliance objectives & .553 & .805 \\
\hline
\end{tabular}


After the step of evaluating the reliability of the scale through Cronbach's Alpha coefficient, the author used the remaining 21 independent variables and 03 dependent variables to analysis of EFA discovery factor. For the analysis of EFA discovery factor, the author used Principal Component extraction method to reduce data and decrease the collinearity among the factors for the next multiple regression analysis, Varimax rotation. The result of EFA initial analysis with the verification value of Bartlett's Test was significant (Sig rate $<0.05$ ), however TTT4 variable has maintained Factor loading $<0.5$, therefore in Table 6 TTT4 variable was not loading for any independent variables. Thus, the author removed TTT4 variable and re-run the analysis of EFA discovery factor which result in KMO 0.0839 coefficient with verification value of Barletta's Test with a significant statistic (Sig rate $<0.05$ ) as Table 5, differential extraction is reached 63,26\% $>50 \%$. Extraction Sum of Squared Loadings Coefficient $=1.265$ satisfy $>$ 1 , as Table 5 satisfies verification requirement, Factor loading coefficient is greater than 0.5 , indicating that the observed variables are correlated with Total Correlation.

\section{Table 5}

The results of KMO and Bartlett's Test of Sphericity

\begin{tabular}{lll}
\hline \multicolumn{2}{l}{ Kaiser-Meyer-Olkin Measure of Sampling Adequacy. } & .839 \\
\hline \multirow{3}{*}{ Bartlett's Test of Sphericity } & Approx. Chi-Square & 1734.249 \\
& Df & 190 \\
& Sig. & .000 \\
\hline
\end{tabular}

The analysis of EFA discovery factor for 03 dependent variables shows that the result of KMO $=0.727$ with Sig rate $<0.05$ in Table 6, Factor loading coefficient is greater than 0.5 , indicating that dependent variables are correlated with each other and Total Correlation (See Table 6). Results of EFA are given in Table 7.

Table 6

The results of EFA test

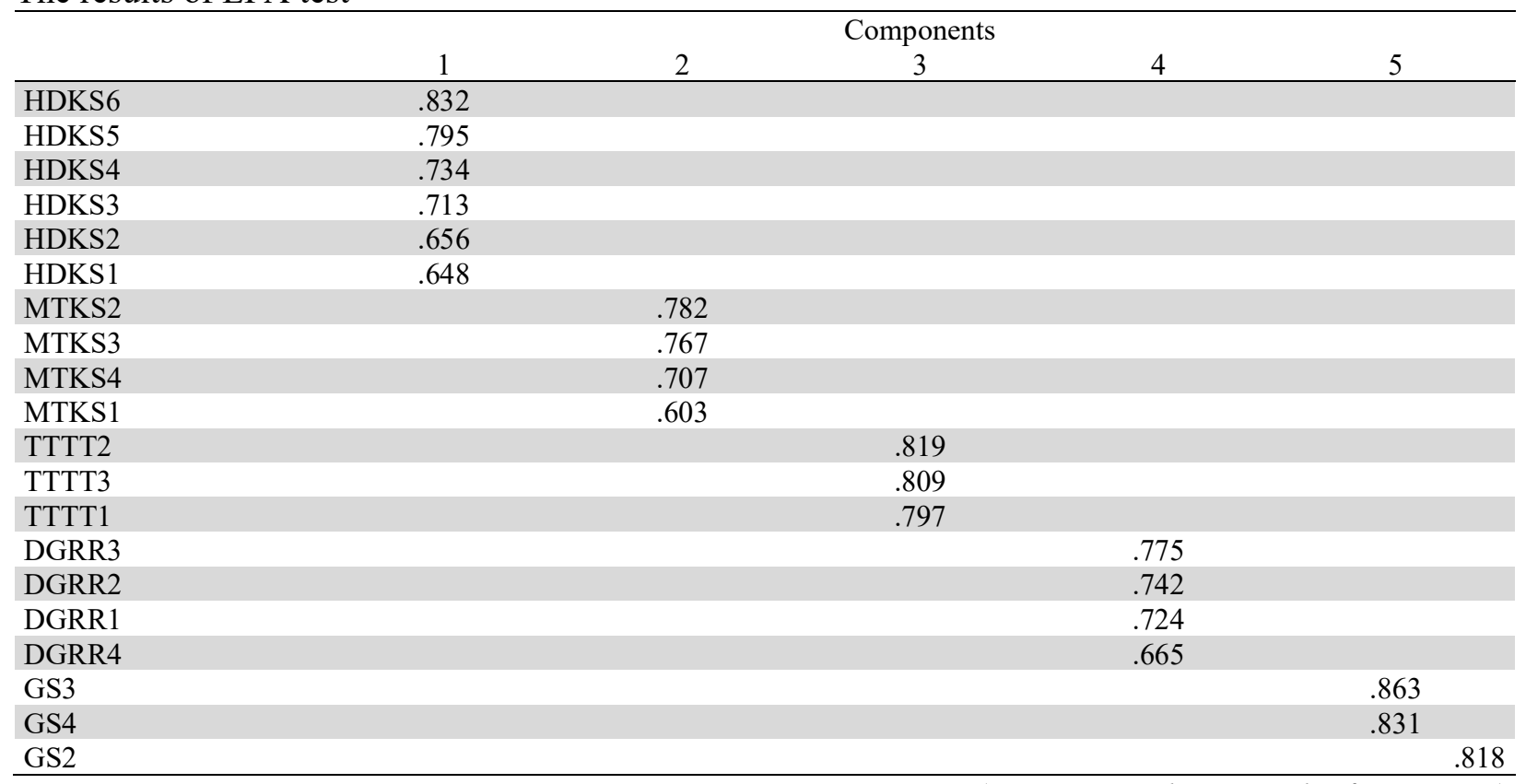

(Source: Analysis results from SPSS) 
Table 7

The results of KMO and Bartlett's Test of Sphericity Kaiser-Meyer-Olkin Measure of Sampling Adequacy.

Bartlett's Test of Sphericity

Approx. Chi-Square

Df

Sig.
(Source: Analysis results from SPSS

After processing, analyzing of EFA discovery factor, the remaining 20 independent variables are used for running of Pearson data to quantify the degree of linear relationship between two quantify variables, if Pearson coefficient $>0.3$ it means that the two variables are correlated. In the Correlations Analysis between 05 independent variables and 01 dependent variable, Table 8 shows that the relationship between "Effectiveness" and 05 " Control Environment", "Risk Assessment", "Information and Communication Systems", "Control Activities" and "Monitoring" variables are significant. Between dependent and independent variables there is a linear correlation (See Table 8).

\section{Table 8}

The results of Pearson correlation test

\begin{tabular}{|c|c|c|c|c|c|c|c|}
\hline & & $\mathrm{HH}$ & MTKS & DGRR & TTTT & HDKS & GS \\
\hline \multirow{3}{*}{$\mathrm{HH}$} & Pearson Correlation & 1 & $.561^{* *}$ & $.355^{* *}$ & $.664^{* *}$ & $.508^{* *}$ & $.386^{* *}$ \\
\hline & Sig. (2-tailed) & & .000 & .000 & .000 & .000 & .000 \\
\hline & $\mathrm{N}$ & 210 & 210 & 210 & 210 & 210 & 210 \\
\hline \multirow{3}{*}{ MTKS } & Pearson Correlation & $.561^{* *}$ & 1 & $.378^{* *}$ & $.450^{* *}$ & $.465^{* *}$ & $.287^{* *}$ \\
\hline & Sig. (2-tailed) & .000 & & .000 & .000 & .000 & .000 \\
\hline & $\mathrm{N}$ & 210 & 210 & 210 & 210 & 210 & 210 \\
\hline \multirow{3}{*}{ ĐGRR } & Pearson Correlation & $.355^{* *}$ & $.378^{* *}$ & 1 & $.239^{* *}$ & $.266^{* *}$ & $.149^{*}$ \\
\hline & Sig. (2-tailed) & .000 & .000 & & .000 & .000 & .030 \\
\hline & $\mathrm{N}$ & 210 & 210 & 210 & 210 & 210 & 210 \\
\hline \multirow{3}{*}{ TTTT } & Pearson Correlation & $.664^{* *}$ & $.450^{* *}$ & $.239^{* *}$ & 1 & $.407^{* *}$ & $.302^{* *}$ \\
\hline & Sig. (2-tailed) & .000 & .000 & .000 & & .000 & .000 \\
\hline & $\mathrm{N}$ & 210 & 210 & 210 & 210 & 210 & 210 \\
\hline \multirow{3}{*}{ HDKS } & Pearson Correlation & $.508^{* *}$ & $.465^{* *}$ & $.266^{* *}$ & $.407^{* *}$ & 1 & $.168^{*}$ \\
\hline & Sig. (2-tailed) & .000 & .000 & .000 & .000 & & .015 \\
\hline & $\mathrm{N}$ & 210 & 210 & 210 & 210 & 210 & 210 \\
\hline \multirow{3}{*}{ GS } & Pearson Correlation & $.386^{* *}$ & $.287^{* *}$ & $.149^{*}$ & $.302^{* *}$ & $.168^{*}$ & 1 \\
\hline & Sig. (2-tailed) & .000 & .000 & .030 & .000 & .015 & \\
\hline & $\mathrm{N}$ & 210 & 210 & 210 & 210 & 210 & 210 \\
\hline
\end{tabular}

\section{Regression analysis}

The method chosen for regression analyze is least square implemented in SPSS software. In Table 9, the value of Adjusted $R$ Square is 79,2\%, which shows the effect level of 05 independent factors in the topic to the effectiveness of Internal control at cement companies is $79.2 \%$. The remaining $20.8 \%$ is due to the influence of other factors to the effectiveness of control. The Durbin-Watson coefficient is 1.589 in the range from 1 to 2 that satisfies the requirement of the test (See Table 9).

Table 9

The results of the statistical test for regression analysis

\begin{tabular}{cccccc}
\hline Model & $\mathrm{R}$ & R Square & Adjusted R Square & Std. Error of the Estimate & Durbin-Watson \\
\hline 1 & $.766^{\mathrm{a}}$ & .797 & .792 & .475 & 1.589 \\
\hline & & & & (Source: Analysis results from SPSS)
\end{tabular}

a. Predictors: (Constant), GS, DGRR, HDKS, TTTT, MTKS

(Source: Analysis results from SPSS)

b. Dependent Variable: HH

According to Table 10, analyzing F shows that we have Sig coefficient smaller than 0.05, which means that the research sample in the topic is meaningful to the whole. 
Table 10

The results of ANOVA test

\begin{tabular}{llccccc}
\hline & Model & Sum of Squares & Df & Mean Square & F & Sig. \\
\hline \multirow{3}{*}{1} & Regression & 65.205 & 5 & 13.041 & 57.892 & $.000^{\text {b }}$ \\
& Residual & 45.953 & 204 & .225 & & \\
\hline & 111.158 & 209 & & & \\
\hline
\end{tabular}

b. Predictors: (Constant), GS, DGRR, HDKS, TTTT, MTKS

a. Dependent Variable: HH

Looking at the standardized coefficients beta given in Table 11, variable DGRR has the lowest number with 0.105 and the highest number belongs to TTTT with 0.427 . In other words, dependent variable has the positive relationship and strongest with independent variable "Information and Communication", on the contrary, the variable has the weakest relationship with dependent variable which is "Risk assessment" and they are all meaningful when the level of significance is five percent.

Form of equation:

$Y=\beta_{1} X_{1}+\beta_{2} X_{2}+\beta_{3} X_{3}+\beta_{4} X_{4}+\beta_{5} X_{5}$

Inside: $\mathrm{X}_{\mathrm{i}}$ is an independent factor group

$\mathrm{X}_{1}$ : Group of Control environment factors

$\mathrm{X}_{2:}$ Group of Risk assessment factors

$\mathrm{X}_{3}$ : Group of Information and Communication system factors

$\mathrm{X}_{4}$ : Group of Control activity

$\mathrm{X}_{5:}$ Group of Monitoring factors

$Y$ : The effectiveness of Internal control

Apply to the result of running model, we have:

$\mathrm{Y}=0.197 \mathrm{X}_{1}+0.105 \mathrm{X}_{2}+0.427 \mathrm{X}_{3}+0.189 \mathrm{X}_{4}+0.154 \mathrm{X}_{5}$

Equation of regression show that, the independent variable and dependent variable in the research model have positive relationships, inside, the most effective variable is "Information and Communication" with the coefficient $\beta_{3}=0.427$ followed by "Control environment" $\beta_{1}=0.197$, "Control activity" $\beta_{4}=0.189$, "Monitoring" $\beta_{5}=0.154$ and "Risk assessment" has the weakest effect to the effectiveness of internal control at cement companies with coefficient $\beta_{2}=0.105$

Table 11

The results of the regression analysis

\begin{tabular}{|c|c|c|c|c|c|c|}
\hline & \multirow{2}{*}{ Model } & \multicolumn{2}{|c|}{ Unstandardized Coefficients } & \multirow{2}{*}{$\begin{array}{c}\text { Standardized Coefficients } \\
\text { Beta }\end{array}$} & \multirow{2}{*}{$\mathrm{T}$} & \multirow{2}{*}{ Sig. } \\
\hline & & $\mathrm{B}$ & Std. Error & & & \\
\hline \multirow{6}{*}{1} & (Constant) & -.817 & .309 & & -2.644 & .009 \\
\hline & HDKS & .231 & .065 & .189 & 3.579 & .000 \\
\hline & MTKS & .247 & .071 & .197 & 3.491 & .001 \\
\hline & TTTT & .434 & .054 & .427 & 8.030 & .000 \\
\hline & DGRR & .123 & .058 & .105 & 2.137 & .034 \\
\hline & GS & .162 & .051 & .154 & 3.200 & .002 \\
\hline
\end{tabular}

\section{Conclusion}

Research result has indicated that Hypotheses $\mathrm{H}_{1}, \mathrm{H}_{2}, \mathrm{H}_{3}, \mathrm{H}_{4}, \mathrm{H}_{5}$ are accepted, which means that Control Environment, Risk assessment, Information and Communication system, Control and Monitoring activities have positive effects to the effectiveness of internal control. The determination and assessment of the influence of factors on the effectiveness of internal control at the cement companies in the current competitive conditions are important. It helps managers identify and accurately assess the factors that have a strong influence on the quality of control, thereby improving the efficiency and effectiveness of 
governance in general and control in particular. Based on the research results, in order to maintain and promote the effectiveness of internal controls at the cement companies, it is necessary to establish closely and systematically the influencing factors including Control Environment, Risk Assessment, Information and Communication Systems, Control Activities as well as Monitoring.

\section{References}

Amudo, A., \& Inanga, E. L. (2009). Evaluation of internal control systems: A case study from Uganda. International Research Journal of Finance and Economics, 27(1), 124-144.

Committee of Sponsoring Organisations of the Treadway Commission (1992). Internal control integrated framework. New York, NY: AICPA.

Committee of Sponsoring Organisations of the Treadway Commission. (2013). The 2013 Internal Control-Integrated Framework. New York, NY: AICPA.

Ho, T.V. (2016). The research of factors affecting the effectiveness of internal control systems in commercial banks-empirical: Evidence in Viet Nam. International Business Research, 9(7).

Gamage, C. T., Lock, K. L., \& Fernando, A. A. J. (2014). A proposed research framework: Effectiveness of internal control system in state commercial banks in Sri Lanka. International Journal of Scientific Research and Innovative Technology, 1(5), 25-44.

Nguyen, P.T. (2018). Effectiveness of the internal control system in the private joint-stock commercial banks in Thai Nguyen province, Vietnam. Proceedings of The $5^{\text {th }}$ IBSM International Conference on Business, Management and Accounting. Hanoi University of Industry, Vietnam, 766-780.

Pham, T.T. (2018). Completing internal control in Vietnamese beer and beverage manufacturing companies. Economic doctoral thesis. Academy of finance, Vietnam.

Rae, K., \& Subramaniam, N. (2008). Quality of internal control procedures: Antecedents and moderating effect on organisational justice and employee fraud. Managerial Auditing Journal, 23(2), 104-124.

Ratcliffe, T. A., \& Landes, C. E. (2009). Understanding internal control and internal control services. American Institute of Certified Public Accountants. New York.

Suyono, E., \& Hariyanto, E. (2012). Relationship between internal control, internal audit, and organization commitment with good governance: Indonesian case. China-USA Business Review, 11(9), 6-13.

The IIA's International Standards 2120 - Risk Management, 2016. Retried fromhttps://www.aiiaweb.it/sites/default/files/imce/pdf/ig2120-2016-12.pdf

Walker, D.M. (1999). Determinants of weaknesses in internal control. Journal of Accounting and Economics, $125,15-23$.

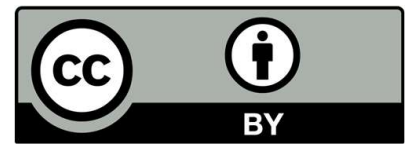

(C) 2020 by the authors; licensee Growing Science, Canada. This is an open access article distributed under the terms and conditions of the Creative Commons Attribution (CCBY) license (http://creativecommons.org/licenses/by/4.0/). 